\title{
Molecular and Pathogenicity Characterization of Sphaceloma manihoticola Isolates from South-Central Brazil
}

\author{
Elizabeth Alvarez and Juan Fernando Mejia, Plant Pathology Program, Centro Internacional de Agricultura \\ Tropical (CIAT), apdo, Aéreo 6713, Cali, Colombia; and Teresa L. Valle, Instituto Agronómico de Campinas \\ (IAC), (019) 3231-5422, Campinas; SP, Brazil
}

\begin{abstract}
Alvarez, E., Mejia, J. F., and Valle, T. L. 2003. Molecular and pathogenicity characterization of Sphaceloma manihoticola isolates from south-central Brazil. Plant Dis. 87:1322-1328.

Isolates of Sphaceloma manihoticola, the asexual stage of Elsinoe brasiliensis, were collected from several regions of south-central Brazil. The isolates were obtained from samples of leaves, stems, and petioles of cassava (Manihot esculenta) and the weedy Euphorbia heterophylla ("amendoim bravo") by directly plating infected tissue onto acidified potato dextrose agar. For pathogenicity studies, 19 isolates were inoculated onto each of two cassava cultivars, MBRA 703 as a susceptible cultivar and MBRA 12 as a resistant cultivar to $S$. manihoticola. MBRA 703 , with the greatest pathogenicity to $58 \%$ (11) of the isolates, showed an intermediate pathogenic reaction to $16 \%$ (3) of the isolates, and was less pathogenic to $26 \%$ (5) of the isolates. MBRA 12, with a less pathogenic reaction to $63 \%$ (12) of the isolates, showed an intermediate pathogenic reaction to $16 \%$ (3) of the isolates, and was highly pathogenic to $21 \%$ (4) of the isolates. The isolates were verified as belonging to the genus Sphaceloma based on their morphological characteristics, including conidia and hyphae of monoconidial isolate. Conidia of isolates were small, thin-walled, ellipsoid to (rarely) globose, commonly with one or two guttules. Conidiophores were phialides, hyaline to slightly pigmented 0-to-1 septate; conidiophores from the weedy specie were phialides, hyaline to brown 0-to-2 septate producing hyaline conidia. The isolates also were verified as belonging to the genus Sphaceloma by using a polymerase chain reaction (PCR) assay, which detected a 645-bp band in all isolates except two (1 and 6) for which the PCR product had $600 \mathrm{bp}$. Digestion of the amplified product with the enzymes $M s p \mathrm{I}$ and $C f o \mathrm{I}$ allowed differences to be detected in restriction patterns among isolates. A homogeneous banding pattern was obtained for 17 of the isolates but a different restriction pattern was obtained for isolates 1 and 6 of E. heterophylla. This suggests the possibility of another species within this group of isolates. The results indicate the presence of pathogenic variation among isolates of the fungus and an isolate-host interaction, because statistically significant differences were observed between the two cassava cultivars in response to inoculation with the isolates of $S$. manihoticola.
\end{abstract}

Additional keywords: superelongation

The importance of cassava (Manihot esculenta Crantz) in tropical regions of the world is growing because of an increase in both consumption of fresh cassava roots and the numerous agro-industrial uses of the crop. World cassava production over the last 10 years averaged 160 million tons/year, with the greatest production in Nigeria, Brazil, and Thailand (5). Brazil, in addition to being one of the largest producers of cassava in the world, has a diversity of cassava production systems (4). An agro-industry of south-central Brazil, close to the Tropic of Capricorn in the states of Santa Catarina, Paraná, São Paulo, and Mato Grosso do Sul, processes nearly 5

Corresponding author: E. Alvarez

E-mail: ealvarez@cgiar.org

Accepted for publication 2 June 2003.

Publication no. D-2003-0908-04R

(C) 2003 The American Phytopathological Society million tons of cassava roots per year (7), approximately $25 \%$ of the national production. Low diversity in this crop, which represents a few improved cultivars with high production potential, supplies the raw material for this industry.

Superelongation, caused by Sphaceloma manihoticola, is one of the major diseases affecting cassava. It was observed and documented for the first time in Brazil in 1950 by Bitancourt and Jenkins (2) in the species M. glaziovii. In Colombia, outbreaks of the disease were reported for the first time in 1972 (3). In 1976, superelongation was reported in Brazil again, in cassava crops near Manaus, Maués, and Bragança in the Amazon region, and in areas surrounding Belém (15). Superelongation was reported a third time in Brazil in 1994 in the state of São Paulo, where the disease was observed in cassava crops in the Valle de Paranapanema, in the municipalities of Assis, Palmital, Ibirarema, and Cândido Mota (16).

Typical symptoms of superelongation include necrotic leaf spots, hypertrophy, and cankers on leaf veins, petioles, and stems. Severely infected plants develop an exaggerated lengthening of the internodes if infected when young $(18,19)$, caused by the hormone gibberellin $\mathrm{A}_{4}$, which weakens the stems and causes dieback and defoliation (18). Superelongation has caused losses of more than $80 \%$ in susceptible cassava cultivars in Colombia, Brazil, Venezuela, and central America (9). In Colombia, dissemination of S. manihoticola was shown to be greater during the rainy season, providing evidence that spores are dispersed by wind and water (10). In south-central Brazil, where winters are dry, dissemination of the pathogen is more limited. Also, the prevalent cold winter temperatures between 15 and $25^{\circ} \mathrm{C}$ in this region restrict plant growth; therefore, little immature tissue is available for infection (T. L. Valle, personal communication). Instead, S. manihoticola is established in such areas and in other areas previously free of superelongation through the introduction of infected cassava planting material. In addition, plant species native to the region, particularly of the genus Manihot, may be hosts of the fungus (20). In addition, there may be different physiological races or biotypes of the fungus, which complicates crop protection programs (13). Studies by Alvarez and Molina (1) confirmed variability in morphology and pathogenicity of $S$. manihoticola isolates from Colombia. They also demonstrated a wide range of genetic diversity in the pathogen population. However, genetic diversity of the population of S. manihoticola in Brazil is unknown. A better understanding of the population of $S$. manihoticola in Brazil is important to design effective disease management strategies. This is particularly important for developing resistant cultivars.

Development of resistance at a given area may not do well in a different geographic region. The objectives of this study were to determine the variability in pathogenicity among isolates of $S$. manihoticola from south-central Brazil and to determine the genetic variability of isolates from this region.

\section{MATERIALS AND METHODS}

Pathogen isolations. S. manihoticola isolates were obtained from cassava plants showing symptoms of superelongation, and 
from the weed Euphorbia heterophylla ("amendoim bravo").

Sampling. Samples were collected at the following locations in south-central Brazil: Paranavaí (in the state of Paraná); Campo Grande (in the state of Mato Grosso do Sul); and Campos Novos, Assis, Platina, Cândido Mota, Echaporã, Conchal, and Campinas (in the state of São Paulo). Fields were selected systematically along the route, assessed only if the cassava crop was infected. At each site, a W-pattern was used.

Isolates of the pathogen were gathered from 48 samples of infected leaves, stems, and petioles ( 2 to $5 \mathrm{~mm}$ in length) of seven cassava cultivars ( $M$. esculenta Fibra, $M$. esculenta IAC13, M. esculenta Roxinha, M. esculenta IAC12, M. esculenta B. Sta Catarina, M. esculenta F1047, and M. esculenta Experimental clone) and from stems and leaves (2 to $5 \mathrm{~mm}$ in length) of E. heterophylla (Table 1). The plant samples were surface disinfested in $1 \%$ sodium hypochlorite for 30 to $60 \mathrm{~s}$ and then in $70 \%$ alcohol for $30 \mathrm{~s}$. The samples then were rinsed in sterile distilled water for $30 \mathrm{~s}$ and dried with sterile, absorbent paper towels. The surface-disinfested samples were placed on acidified potato dextrose agar (PDA) prepared as follows. Peeled potatoes $(200 \mathrm{~g}$ ) were cooked for $20 \mathrm{~min}$ in 300 $\mathrm{ml}$ of distilled water. The potatoes and liquid were pureed and distilled water was added to a volume of $1,000 \mathrm{ml}$. Dextrose $(17 \mathrm{~g})$ and granulated agar (18 g) (Fisher Scientific, Springfield, NJ) were mixed together and added to the pureed potato. The suspension then was autoclaved at $120^{\circ} \mathrm{C}$ and 15 psi for $15 \mathrm{~min}$ and supplemented with $25 \%$ lactic acid added for a final concentration of $0.25 \%$ and streptomycin at $100 \mathrm{ppm}$. Single spore isolates of S. manihoticola that developed were subcultured onto PDA and incubated at $28^{\circ} \mathrm{C}$ in the dark for 15 to 30 days. The isolates were maintained on PDA plates. To store the isolates for extended periods of time, they were transferred onto PDA slants in test tubes and kept at $4^{\circ} \mathrm{C}$. Nineteen isolates of S. manihoticola were colleted.

Pathogenicity of isolates of S. manihoticola. Isolates of $S$. manihoticola were inoculated onto 45-day-old cassava plants that had been propagated vegetatively. Under greenhouse conditions ( 25 to $28^{\circ} \mathrm{C}$ ), $10-\mathrm{cm}$-long stem cuttings were planted in $12.7-\mathrm{cm}$ pots that contained a mixture of soil and sand (2:1) that had been pasteurized. The 19 isolates of S. manihoticola were inoculated under greenhouse conditions $\left(26^{\circ} \mathrm{C}\right.$ at night to $28^{\circ} \mathrm{C}$ during the day; relative humidity was kept between 98 and $100 \%$ for $72 \mathrm{~h}$ ) with single conidium to superelongation onto two cassava cultivars that had previously been evaluated in field trials using a scale based on symptom appearance, where the plants with no visible symptoms or a few cankers on leaves were considered resistant; the plants with a lot of cankers on leaves or petioles or stems, with severe leaf distortion, scorching, elongation, and dieback, were considerate susceptible and rated as resistant MBRA 12 and susceptible MBRA 703 to superelongation (data not shown). Pathogenicity on cassava of two isolates of Sphaceloma from E. heterophylla also was determined. A split-plot experiment arranged in a randomized complete block design with four replicates was used. The main plot treatments were the cultivars of cassava. Subplot treatments were 19 isolates of $S$. manihoticola selected randomly and a control treatment (inoculated with sterile distilled water and Tween 20). A split-plot experiment design with four replicates was used, where the main plots were the cultivars and the subplots the isolates. Two plants were inoculated per experimental unit with eight plants per treatments, and the average of both plants was calculated (Table 2).

Inoculum was prepared from single spore isolates by surface scraping the mycelium to avoid agar and suspending $25-$ to 30 -day-old cultures of each isolate in $40 \mathrm{ml}$ of sterile distilled water (containing $200 \mu \mathrm{l}$ of Tween 20). The spore concentration was

Table 1. Origin of 19 isolates of Sphaceloma manihoticola, and pathogenicity of these isolates to two cultivars of cassava (Manihot esculenta), MBRA 703 and MBRA 12, in south-central Brazil

\begin{tabular}{|c|c|c|c|c|c|c|c|c|}
\hline \multirow[b]{2}{*}{ Isolate } & \multirow[b]{2}{*}{ Origin $^{b}$} & \multirow[b]{2}{*}{ Host } & \multirow[b]{2}{*}{ Part $^{c}$} & \multicolumn{2}{|c|}{ Combined pathogenicity ${ }^{a}$} & \multirow[b]{2}{*}{ Average $^{d}$} & \multirow[b]{2}{*}{ Pathogenicity $^{\mathrm{e}}$} & \multirow[b]{2}{*}{ RAPD } \\
\hline & & & & MBra 703 & MBra 12 & & & \\
\hline 1 & Campos Novos (SP) & Euphorbia heterophylla & Stem & 29.53 & 22.75 & 3.0 & 2 & 1 \\
\hline 2 & Campos Novos (SP) & M. esculenta Fibra & Leaf & 21.61 & 13.34 & 1.7 & 1 & 2 \\
\hline 3 & Campos Novos (SP) & M. esculenta IAC-13 & Leaf & 22.49 & 12.57 & 1.9 & 1 & 2 \\
\hline $4 \mathrm{p}$ & Paranavai (PR) & M. esculenta IAC-13 & Petiole & 24.28 & 20.43 & 2.6 & 2 & 2 \\
\hline 5 & Assis (SP) & M. esculenta IAC-13 & Leaf & 28.83 & 19.38 & 2.7 & 2 & 2 \\
\hline 6 & Conchal (SP) & E. heterophylla & Stem & 16.58 & 12.07 & 1.4 & 4 & 1 \\
\hline $7 \mathrm{~h}$ & Platina (SP) & M. esculenta Roxinha & Leaf & 26.12 & 24.67 & 2.8 & 2 & 2 \\
\hline $7 \mathrm{p}$ & Platina (SP) & M. esculenta Roxinha & Petiole & 21.83 & 15.53 & 2.1 & 1 & 2 \\
\hline 8 & Cândido Mota (SP) & M. esculenta IAC-13 & Leaf & 24.68 & 16.88 & 2.6 & 3 & 2 \\
\hline 9 & Conchal (SP) & M. esculenta IAC-12 & Leaf & 21.67 & 11.16 & 1.7 & 1 & 2 \\
\hline 10 & Conchal (SP) & M. esculenta B. S. Catarina & Leaf & 23.84 & 12.99 & 1.8 & 1 & 5 \\
\hline $11 \mathrm{p}$ & Conchal (SP) & M. esculenta Fibra & Petiole & 24.54 & 15.14 & 2.1 & 3 & 2 \\
\hline 12 & Conchal (SP) & M. esculenta IAC-13 & Leaf & 21.79 & 18.99 & 2.3 & 3 & 4 \\
\hline $13 \mathrm{~h}$ & Echaporá (SP) & M. esculenta Roxinha & Leaf & 24.72 & 16.71 & 2.3 & 3 & 4 \\
\hline 14 & Campos Novos (SP) & M. esculenta Roxinha & Leaf & 19.43 & 16.49 & 2.0 & 1 & 4 \\
\hline 15 & Campos Novos (SP) & M. esculenta B. S. Catarina & Leaf & 21.74 & 13.87 & 1.8 & 1 & 4 \\
\hline $\mathrm{Bh}$ & Campo Grande (MS) & M. esculenta Unknown cultivar & Leaf & 27.70 & 19.95 & 2.7 & 2 & 3 \\
\hline $25 \mathrm{~h}$ & Campinas (SP) & M. esculenta F1047 & Leaf & 27.83 & 19.69 & 2.6 & 2 & 4 \\
\hline $26 \mathrm{~h}$ & Campinas (SP) & M. esculenta experimental clone & Leaf & 20.48 & 14.61 & 2.0 & 1 & 3 \\
\hline Control & $\ldots$ & $\cdots$ & $\ldots$ & 10.50 & 10.50 & 1.0 & $\ldots$ & $\ldots$ \\
\hline
\end{tabular}

a Analysis of combined experiments. A split-plot experiment arranged in a randomized complete block design was repeated. Main plot treatments were cultivars of cassava. Split-plot treatments were 19 isolates of $S$. manihoticola plus a control (inoculated with water).

b Abbreviations for states: SP = State of São Paulo; PR = State of Paraná; MS = State of Mato Grosso do Sul.

c Plant part from which isolate was obtained. The area under disease progress curve (AUDPC) were calculated 7 and 14 days after inoculation using a scale based on symptom appearance, where $1=$ plants with no visible symptoms; 2 = spots or cankers on leaves or petioles; $3=$ cankers on leaves, petioles, and stems, with severe leaf distortion; and 4 = elongation, cankers on leaves, petioles, and stems, severe leaf distortion and scorching.

d Average of damage, based on a scale of 1 to 4 (symptom appearance).

e Pathogenicity groups. The isolates were separated into four groups based on the disease severity rating of the two inoculated cultivars of cassava, using Ward's cluster analysis with level of confidence of 93\%: Group 1 was formed by eight isolates with low pathogenicity (AUDPC = 17.72); group 2 included four isolates with intermediate pathogenicity (AUDPC $=20.43$ ); group 4 consisted of one isolate with a mean AUDPC value of only 12.41 and is less pathogenic; and group 3, containing six isolates, had the highest mean AUDPC value, indicating that these isolates are more pathogenic than isolates in the others groups.

${ }^{f}$ Groups were formed using genetic similarity among the isolates calculated with the Nei-Li coefficient and SAHN clustering using the unweighted pair group mean arithmetic average method of the NTSYS-PC (version 2.02, statistical package). 
adjusted to $3 \times 10^{6}$ conidia $/ \mathrm{ml}$ using a hemacytometer (Sigma-Aldrich, St. Louis). Each stem and petiole to be inoculated was cleaned with a cotton-tipped applicator dampened with sterile distilled water, to remove the waxy layer of the plant for easier fungal penetration. Each plant then was inoculated by spraying $50 \mathrm{ml}$ of the conidial suspension using a Devilbiss sprayer (Devilbiss glass nebulizer 45; Fisher Scientific, Springfield, NJ). Plants then were incubated in a humidity chamber with temperatures ranging from $26^{\circ} \mathrm{C}$ at night to $28^{\circ} \mathrm{C}$ during the day. Relative humidity was kept between 98 and $100 \%$ for $72 \mathrm{~h}$ and then between 50 and $80 \%$ at the same temperature. The humidity chamber consisted of 2-mil clear, plastic greenhouse covering on an aluminum frame $493 \mathrm{~cm}$ wide by $180 \mathrm{~cm}$ long by $250 \mathrm{~cm}$ deep.

The area under disease progress curve (AUDPC) was calculated using a scale based on symptom appearance, where $1=$ plants with no visible symptoms; $2=$ spots or cankers on leaves or petioles; $3=$ cankers on leaves, petioles, and stems, with severe leaf distortion; and 4 = elongation, cankers on leaves, petioles, and stems, severe leaf distortion, and scorching (International Center of Tropical Agriculture [CIAT] Cassava Pathology program). The evaluations for disease development were conducted 7 and 14 days after inoculation. Analyses of variance of the AUDPC values were analyzed using the general linear models procedure (PROC GLM) in SAS (version 6, statistical package; Cary, NC). Significant differences among means for disease severity at each isolate were determined using the Fisher's protected least significant difference (LSD; $P=0.05$ ), and $t$ tests with least-squares means were used to compare isolates with cultivar. The isolates were separated in groups based on the disease severity ratings of the two inoculated cultivars of cassava, using Ward's cluster analysis in SAS (Table 1). The experiment was performed two times and means were pooled across experiments for analysis because variances were homogeneous (12).

Table 2. Analysis of variance (ANOVA) for pathogenicity of 19 isolates of Sphaceloma manihoticola obtained from south-central Brazil and inoculated onto two cassava cultivars (MBRA 703 and MBRA 12)

\begin{tabular}{lccc}
\hline Source of variation & df & Pathogenicity (mean square) & $\boldsymbol{P r}>\boldsymbol{F}$ \\
\hline Experiment & 1 & $331.81 * *$ & 0.0001 \\
Replications (experiment) & 7 & $116.13 * *$ & 0.0001 \\
Isolates & 19 & $239.59 * *$ & 0.0001 \\
Experiment $\times$ isolate & 19 & $2.82 \mathrm{NS}$ & 0.9999 \\
Cultivars & 1 & $3,507.61 * *$ & 0.0001 \\
Experiment $\times$ cultivar & 1 & $265.62 * *$ & 0.0001 \\
Cultivar $\times$ isolate & 19 & $38.42 * *$ & 0.0002 \\
Experiment $\times$ isolate $\times$ cultivar & 19 & $1.54 \mathrm{NS}$ & 1.0000 \\
Coefficient of variation $(\%)$ & 18.9 & $\ldots$ & $\ldots$ \\
\hline
\end{tabular}

a ANOVA was performed on two combined experiments; 20 treatments were inoculated in two cassava cultivars and arranged in a randomized complete block design of a split-plot experiment with eight plants-treatments and four replicates; ** and NS represent significant effects at $P \leq 0.01$ and no significance at $P<0.05$, respectively.

Molecular characterization of $S$. manihoticola. Tests for molecular characterization of the isolates of S. manihoticola were done according to the protocols of Lee and Taylor (8). The molecular weights of polymerase chain reaction (PCR) products were determined according to the ONE Discan (version 1.0; Scanalytics, Inc. Billerica, MA). A disc of $5 \mathrm{~mm}$ of fungal isolates was placed in $50 \mathrm{ml}$ of $\mathrm{V} 8$ broth (1 liter of $\mathrm{V} 8$ juice agar and $14 \mathrm{~g}$ of $\mathrm{CaCO}_{3}$; the mixture was centrifuged at $4^{\circ} \mathrm{C}$ for 15 min at 5,000 rpm and $200 \mathrm{ml}$ of the supernatant was recovered completing with 800 $\mathrm{ml}$ of distilled water) and incubated under constant agitation $(100 \mathrm{rpm})$ with a gyratory platform shaker (Fisher Scientific, Springfield, NJ), for 15 days at 26 to $28^{\circ} \mathrm{C}$ in the dark. The mycelium was collected from the flasks, strained through filter paper (Whatman No. 1) using a vacuum bell, and macerated in liquid nitrogen to obtain a fine dry powder. Next, $450 \mu \mathrm{l}$ (or an equal volume of lysis buffer) of a solution of phenol: chloroform:isoamyl alcohol (2:2:1) was added, and the mixture was gently inverted until a homogeneous consistency was obtained. Isopropanol $(300 \mu \mathrm{l})$ was added, mixed by inverting, and left to precipitate for 12 to $14 \mathrm{~h}$ at $-20^{\circ} \mathrm{C}$. The mixture was centrifuged at $10,000 \times g$ for 5 min, and the supernatant decanted. The resulting pellet was washed with $300 \mu \mathrm{l}$ of $70 \%$ ethanol, centrifuged again at $10,000 \times$ $g$ for $5 \mathrm{~min}$, and the supernatant discarded. The tubes were inverted on sterile paper for $15 \mathrm{~min}$ and dried in a vacuum bell for 1 $\mathrm{h}$. The DNA obtained was resuspended in 50 to $100 \mu \mathrm{l}$ of TE buffer $(0.1 \mathrm{mM}$ Tris$\mathrm{HCl} ; 10 \mathrm{mM}$ EDTA, pH 8.0), $10 \mu \mathrm{l}$ of RNase was added, and the mixture was incubated at $37^{\circ} \mathrm{C}$ for $30 \mathrm{~min}$. The concentration of DNA was determined with a Hoefer Scientific Instruments, San Francisco), diluted in filter-sterilized $(0.2-\mu \mathrm{m}$ filter), bi-distillate water to a concentration of $5 \mathrm{ng} / \mu \mathrm{l}$, and stored at $-20^{\circ} \mathrm{C}$.

The internal transcribed spacer (ITS) region of ribosomal DNA was amplified by PCR with primers ITS4 and ITS5 (Operon Technologies, Inc., Alameda, CA) using

1324 Plant Disease / Vol. 87 No. 11 the following reagents: a buffer Taq to a final concentration of $1 \times$ (Promega Corp., Madison, WI), $0.2 \mathrm{mM}$ dNTPs (dATP, dCTP, dGTP, and dTTP), $0.5 \mu \mathrm{M}$ of each primer (ITS4 and ITS5), $2.5 \mathrm{mM} \mathrm{MgCl}_{2}$, and $2 \mu \mathrm{l}$ of DNA at $5 \mathrm{ng} / \mu \mathrm{l}$ for each sample. Just before adding the DNA, Taq polymerase (Promega Corp.) at 0.625 units $/ \mu \mathrm{l}$ was added, and the volume brought to 25 $\mu \mathrm{l}$ using filter-sterilized (0.2- $\mu \mathrm{m}$ filter), bidistillate water. As a negative control, the DNA sample was replaced with filtersterilized $(0.2-\mu \mathrm{m}$ filter $)$, bi-distillate water. The reaction was carried out in $0.25-\mathrm{ml}$ PCR tubes which were placed in a PTC 100 thermocycler (Programmable Thermal Controller; MJ Research, Inc., Waltham, MA), and run at: $95^{\circ} \mathrm{C}$ for $3 \mathrm{~min}, 57^{\circ} \mathrm{C}$ for $30 \mathrm{~s}, 72^{\circ} \mathrm{C}$ for $2 \mathrm{~min}$, and $95^{\circ} \mathrm{C}$ for $30 \mathrm{~s}$ for 24 cycles; $50^{\circ} \mathrm{C}$ for $30 \mathrm{~s} ; 72^{\circ} \mathrm{C}$ for $10 \mathrm{~min}$; and then held overnight at $4^{\circ} \mathrm{C}(1)$.

All electrophoresis was done using $1.5 \%$ agarose gel in a buffer of $1 \times$ TBE (Trisborate EDTA) (6) and ethidium bromide with a final concentration of $0.75 \mu \mathrm{g} / \mathrm{ml}$. The electrophoresis chamber was maintained at $90 \mathrm{~V}$ for $90 \mathrm{~min}$. A 100-bp marker (Invitrogen Life Technologies., Carlsbad, CA) was used.

A $15-\mu$ subsample of the PCR product was added to $2 \mu \mathrm{l}$ of the undiluted $10 \times$ buffer of enzyme, after which $1 \mu \mathrm{l}$ of restriction enzyme (listed below, $500 \mathrm{unit} / \mu \mathrm{l}$ ) was added. This suspension was incubated for $16 \mathrm{~h}$ at $37^{\circ} \mathrm{C}$, after which $3 \mu \mathrm{l}$ of running buffer (6) (bromophenol blue, 0.25\%, and glycerol in water, 30\%) was added. A $2.0 \%$ agarose gel was prepared as above and placed in an electrophoresis chamber for $10 \mathrm{~h}$ at $80 \mathrm{~V}$. In each gel, a 100-bp marker was included. The product generated by the PCR technique was digested with the enzymes MspI, CfoI, HinfI, HaeIII, and TaqI (Invitrogen Life Technologies).

Random amplified polymorphic DNA analysis. An amplification suspension was prepared in a microcentrifuge tube $(1.5 \mathrm{ml})$ for each sample using a buffer Taq to a final concentration of $1 \times$ (Promega Corp.); $0.2 \mathrm{mM}$ dNTPs (dATP, dCTP, dGTP, and dTTP); $0.5 \mu \mathrm{M}$ random primer (Operon Technologies, Inc.); $2.5 \mathrm{mM} \mathrm{MgCl} 2$; and 4 $\mu \mathrm{l}$ of DNA at $5 \mathrm{ng} / \mu \mathrm{l}$. After adding Taq polymerase at 0.625 units/ $\mu \mathrm{l}$, the volume was brought to $25 \mu \mathrm{l}$ with filter-sterilized $(0.2-\mu \mathrm{m}$ filter), bi-distillate water, and maintained at $4^{\circ} \mathrm{C}$. For the negative control treatment, DNA was replaced with filtersterilized $(0.2-\mu \mathrm{m}$ filter $)$, bi-distillate water. The reaction was carried out in $0.25-\mathrm{ml}$ PCR tubes, which were placed in the PTC100 thermocycler and run at the following parameters: $94^{\circ} \mathrm{C}$ for $55 \mathrm{~s}, 94^{\circ} \mathrm{C}$ for $35 \mathrm{~s}$, $36^{\circ} \mathrm{C}$ for $1 \mathrm{~min}$, and $72^{\circ} \mathrm{C}$ for $2 \mathrm{~min}$, for 40 cycles; $72^{\circ} \mathrm{C}$ for $8 \mathrm{~min}$; and then held overnight at $4^{\circ} \mathrm{C}$.

The amplified fragments were analyzed in a $1.5 \%$ agarose gel as above for $12 \mathrm{~h}$ at $60 \mathrm{~V}$. Fifteen random primers were evalu- 
ated (Operon Technologies, Inc.; Table 3). Of the 15 random amplified polymorphic DNA (RAPD) primers evaluated, OPA-01, OPA-02, and OPA-03 were selected for molecular characterization of the fungal isolates because they showed between 20 and 25 reproducible polymorphic bands for all of the isolates. Genetic similarities among the isolates were calculated using the Nei-Li coefficient, $S$, where $S=2 a /(2 a$ $+b+c$ ), where $a=$ bands shared by both isolates, $b=$ bands present in isolate 1 but not in isolate 2 , and $c=$ bands presented in isolate 2 but not in isolate 1 . Dendrograms were constructed with SAHN clustering of the NTSYSpc statistical package (version 2.02i, F. J. Rohlf; Exeter Software, Setauket, NY), using the unweighted pair group mean arithmetic average method. A binary data matrix was prepared in which $1=$ band present and $0=$ band absent.

The groups obtained with the Nei-Li coefficient with which they were correlated were obtained with the Ward's cluster analysis using SAS (Table 1).

\section{RESULTS}

Pathogenicity of isolates of S. manihoticola. Symptoms observed after inoculation of cassava plants with the isolates of $S$. manihoticola included small, necrotic leaf spots; slightly chlorotic lamina with numerous circular spots, sometimes with perforated dark margins, thus deforming the leaf; elongated, protuberant lesions along leaf veins; and brown or yellow cankers with slightly dark borders on stems and petioles. In the first evaluation (7 days after inoculation), symptoms were observed only on leaves. In the second evaluation (14 days after inoculation), symptoms were more severe and more prevalent, with lesions on petioles, and stems and leaves showing obvious distortion (Fig. 1). Symptoms characteristic of the disease were observed on leaves 7 days after inoculation and on stems 10 to 12 days post inoculation.

The variable pathogenicity of the 19 isolates was not affected significantly by replications or between experiments; in turn, significant differences in virulence were found among the isolates and cultivars. These interactions were submitted to analysis of variance (Fig. 2 and Table 2). There was also a significant isolate-cultivar interaction. The isolates were separated into four groups based on the disease severity ratings of the two inoculated cultivars of cassava, using Ward's cluster analysis with a level of confidence $93 \%$. Group 1 was formed by eight isolates (no. $2,3,7 \mathrm{p}, 9,10,14,15$, and $26 \mathrm{~h}$ ) with an average AUDPC value of 17.72. The pathogenicity of the isolates of this group was low relative to the other groups. Group 2 included isolates $8,11 \mathrm{p}, 12$, and $13 \mathrm{~h}$, with a mean AUDPC value of 20.43. Group 3 contained isolates $1,4 \mathrm{p}, 5,7 \mathrm{~h}, 25 \mathrm{~h}$, and $\mathrm{Bh}$, with a mean AUDPC value of 24.26.
Table 3. List of primers used for random amplified polymorphic DNA analyses and their sequences

\begin{tabular}{ll}
\hline Primers $^{\mathbf{a}}$ & Sequence of the primers $\left(\mathbf{5}^{\prime} \mathbf{-} \mathbf{3}^{\prime}\right)$ \\
\hline OPA-01 & CAGGCCCTTC \\
OPA-02 & TGCCGAGCTG \\
OPA-O3 & AGTCAGCCAC \\
OPA-07 & GAAACGGGTG \\
OPA-11 & CAATCGCCGT \\
OPA-18 & AGGTGACCGT \\
OPN-18 & GGTGAGGTCA \\
OPH-13 & GACGCCACAC \\
OPF-01 & ACGGATCCTG \\
PERY2 & CTG TTC CGG CGT AAG CTG G \\
PNIC1 & ATT CAA AAG CCA AGC CAC CG \\
PPP1 & CTG ACG ATC CAG ATC CTC TGC ACG \\
PPP2 & CTT GCG AGG CTT GAC CGC TTC CTA \\
PPC1 & GTC GAC GTC CTG CTT GGC ACT CTG \\
PPC2 & CGG TGC TCC GCG ACT GTT GTC CAC \\
\hline
\end{tabular}

a Operon Technologies, Inc., Alameda, CA.

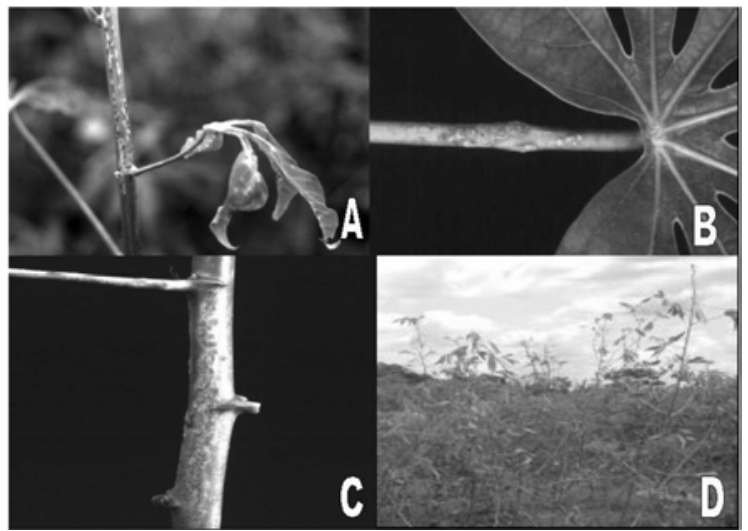

Fig. 1. A, Cankers on stem and leaves, with severe leaf distortion. B, Cankers on petioles. C, Cankers on petiole and stem. D, Elongation; cankers on leaves, petioles, and stems; severe leaf distortion; and scorching. Cassava Phytopathology Program.

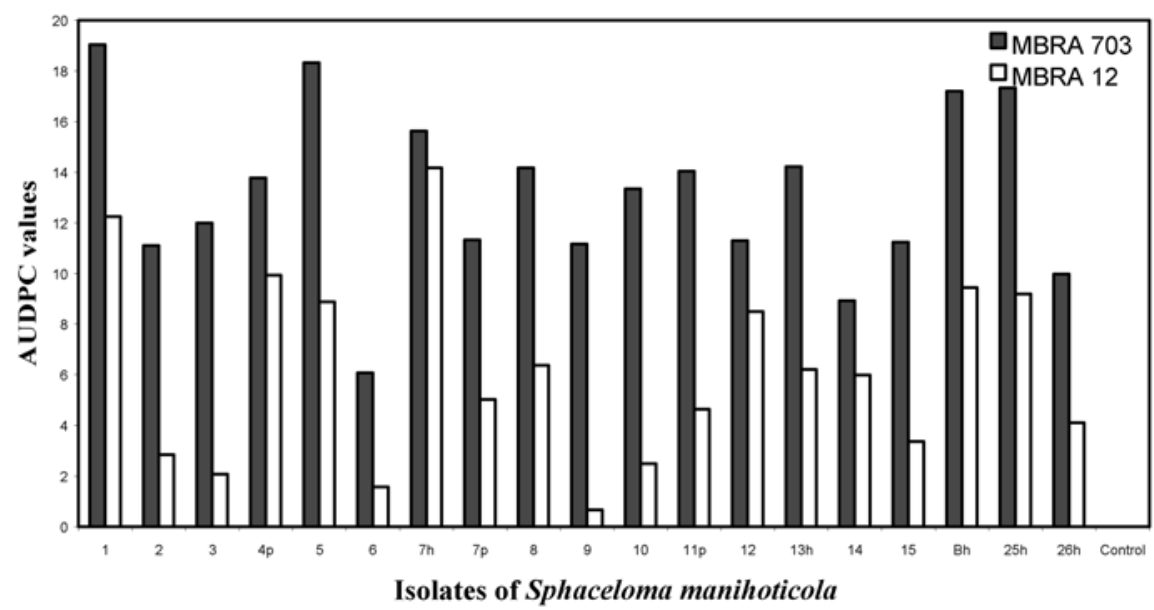

Fig. 2. Two cultivars of cassava (Manihot esculenta), MBRA 703 and MBRA 12, compared for their susceptibility to superelongation disease caused by Sphaceloma manihoticola. AUDPC = area under the disease progress curve. The main plot treatments were the cultivars of cassava. Subplot treatments were 19 isolates (no. 1, 2, 3, 14, and 15 from Campos Novos; 4p from Paranavaí; 5 from Assis; 6, 9, 10, 11p, and 12 from Conchal; $7 \mathrm{~h}$ and $7 \mathrm{p}$ from Platina; 8 Candido Mota; $13 \mathrm{~h}$ from Echaporá; Bh from Campo Grande; $25 \mathrm{~h}$ and $26 \mathrm{~h}$ from Campinas) of S. manihoticola and a control treatment (inoculated with sterile distilled water). Two plants were inoculated per experimental unit and inoculated in optimal controlled greenhouse conditions to superelongation onto two cassava cultivars that previously had been evaluated in field trials and rated as resistant (MBRA 12) and susceptible (MBRA 703) to superelongation. Evaluations for disease development were conducted 7 and 14 days after inoculation. A split-plot experiment arranged in a randomized complete block design with eight replicates was used. The experiment was replicated and the results were combined for two experiments. The data were analyzed using SAS (version 6, statistical package; Cary, NC). 
This group had the highest mean AUDPC value, indicating that these isolates are more pathogenic than isolates in the others groups. Group 4 was formed by one isolate (no. 6) with a mean AUDPC value of only 12.41. This isolate is pathogenic.

Based on the average AUDPC of both of the cultivars evaluated, the minimum value found was 10.5, for the control inoculated with water that did not present visible symptoms. The maximum value was 26.14 , with symptoms appearing all over the plant. These values correspond to a ranking between 1.0 and 3.0, indicating that the values closest to 10.5 correspond to isolates with a low level of pathogenicity and those close to or above 26.14 correspond to isolates that cause plant damage. Mean AUDPC values resulting from inoculation of MBRA 703 with isolates of S. manihoticola ranged from 16.58 to 29.53; whereas, for MBRA 12, the mean AUDPC values ranged from 11.16 to 24.67 , indicating a higher degree of pathogenicity in MBRA 703 than MBRA 12. MBRA 12 showed a low pathogenicity reaction to $63.1 \%$ of isolates evaluated, an intermediate reaction

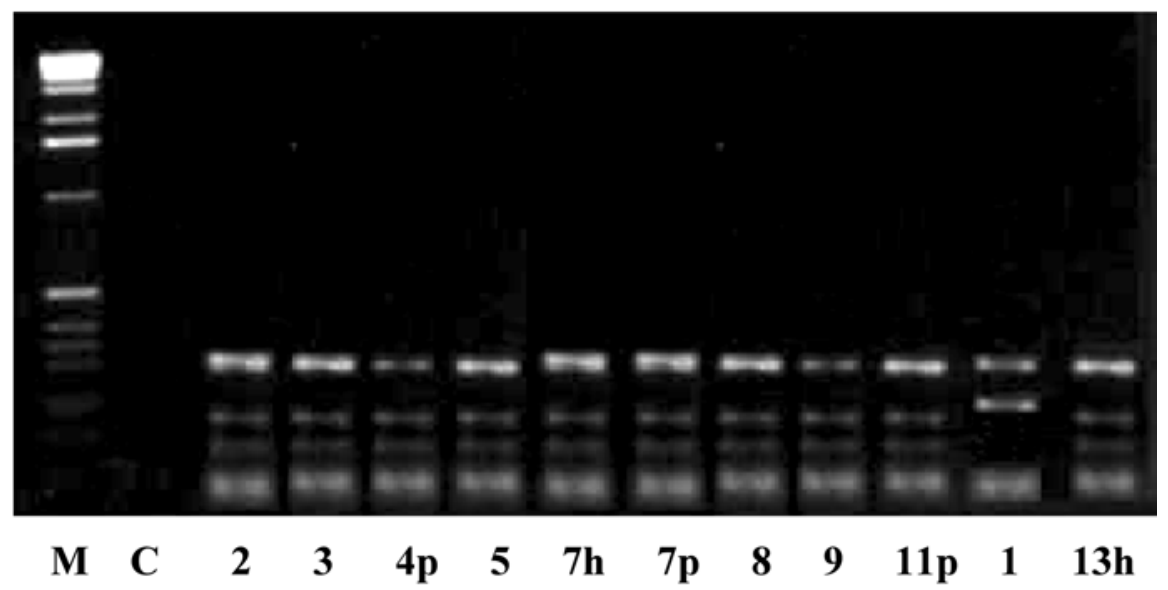

Fig. 3. Electrophoresis of internal transcribed spacer fragments of DNA extracted from isolates of Sphaceloma manihoticola and digested with the endonuclease $M s p \mathrm{I} . \mathrm{M}=\operatorname{marker}(1 \mathrm{~kb}) ; \mathrm{C}=$ control; isolates of $S$. manihoticola from lanes 2 and $3=$ Campos Novos, lane $4 \mathrm{p}=$ Paranavaí, lane $5=$ Assis, lanes $7 \mathrm{~h}$ and $7 \mathrm{p}=$ Platina, lane $8=$ Candido Mota, lanes 9 and $11 \mathrm{p}=$ Conchal, lane $13 \mathrm{~h}=$ Echaporá; and lane $1=$ isolate of Euphorbia heterophylla from Conchal, Brazil.

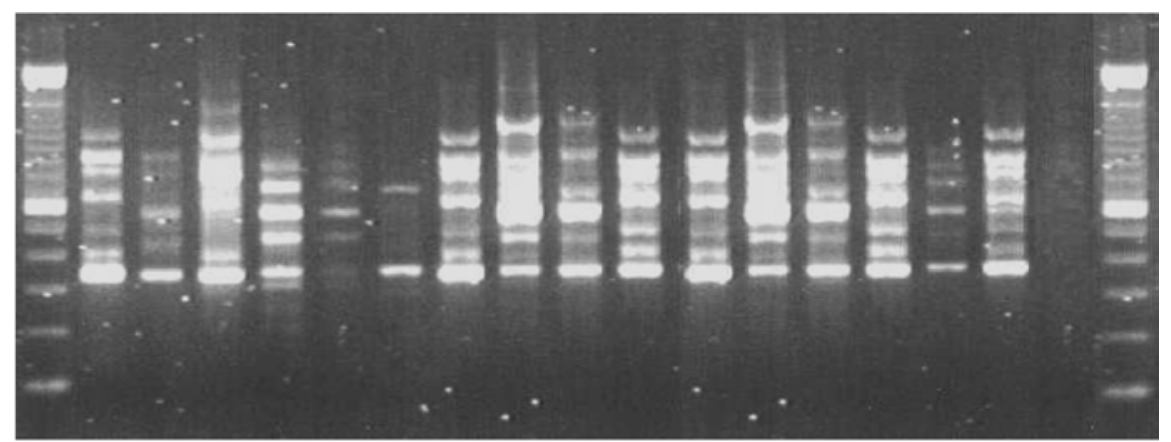

\section{$\begin{array}{lllllllllllllllllll}M & 1 & 2 & 3 & 4 & 5 & 6 & 7 & 8 & 9 & 10 & 11 & 12 & 13 & 14 & 15 & 16 & C & M\end{array}$}

Fig. 4. Banding patterns obtained with the primers OPA-01 (lanes 1 to 6), OPA-02 (lanes 7 to 12), and OPA-03 (lanes 13 to 16) used to characterize 19 isolates of Sphaceloma manihoticola collected from Campos Novos $=$ lanes 1, 2, 7, 8, 13, and 14; Paranavaí $=$ lanes 3, 9, and 15; Conchal $=$ lanes 4, 10, and 16; and Platina $=$ lanes 5, 6, 11, and 12; $\mathrm{M}=100$-bp marker; $\mathrm{C}=$ control. were intermediate. Isolates 10 and $11 \mathrm{p}$ of Conchal, isolate 8 of Candido Mota, and isolate $13 \mathrm{~h}$ of Echaporá showed a high pathogenicity for MBRA 703, whereas that for MBRA 12 was low. Isolate 5 of Assis, isolate 25h of Campinas (São Paulo), and isolate Bh of Campo Grande (Mato Grosso do Sul) had an intermediate pathogenicity for MBRA 12 and high pathogenicity for MBRA 703.

Molecular characterization of $S$. manihoticola. The size of the amplified product was $645 \mathrm{bp}$ for all isolates of $S$. manihoticola except isolates 1 and 6 , for which the PCR product was $600 \mathrm{bp}$ in size. Digestion of the PCR products with $M s p \mathrm{I}$ and $C f o \mathrm{I}$ resulted in different pattern of bands. This places the isolates in two groups and indicates that they belong to two species (Fig. 3).

RAPD analysis yielded between 20 and 25 bands per isolate or specific banding for the different primers (Fig. 4). The dendrogram constructed from the RAPD analysis of the isolates of $S$. manihoticola separates the 19 isolates into five groups, with a similarity level of 0.6 (Fig. 5). One primer group was formed by isolates 1 and 6 , which originated from E. heterophylla and were collected in the state of São Paulo. This plant species is a common weed in cassava crops. The second group was formed by isolates from the states of São Paulo, Paraná, and Mato Grosso do Sul. Isolates $4 p$ and 3 , obtained from cv. IAC13 in Paranavaí (Paraná) and Campos Novos (São Paulo), were very similar (similarity index $=0.75$ ). The isolates $\mathrm{Bh}$ of Campo Grande (Mato Grosso do Sul) and 26h from Campinas (São Paulo) were separated from the second group, presenting a third genetic line. A fourth group was formed by isolates $12,15,13 \mathrm{~h}, 14$, and $25 \mathrm{~h}$, which were isolated from different cultivars of cassava and collected from various municipalities of the state of São Paulo. A fifth group was formed by a single isolate, isolate 10 from Conchal, São Paulo. Within the different groups, isolates diverged little from each other.

The correlation between the groups obtained with the Nei-Li coefficient and those obtained with Ward's cluster analysis was low $(0.08 \%)$.

\section{DISCUSSION}

This study attempted to determine the genetic diversity and pathogenicity of $S$. manihoticola, a fungus causing superelongation disease in cassava (M. esculenta), an economically important root crop. A fungal population was isolated from cassava grown in south-central Brazil, and molecular analyses was conducted to discover the level of genetic variation among the isolates. The analyses also attempted to clearly differentiate between isolates attacking cassava from those attacking milkweed (E. heterophylla), a susceptible host plant that is 
found frequently in cassava-growing areas of Brazil.

According to Zeigler (17), the conidia of $S$. manihoticola isolates from cassava are small, unicellular, and hyaline, whereas conidia of $S$. krugii (which also causes superelongation disease) from milkweed are large, pigmented, and spindle shaped. However, we found that colony morphology and color were insufficient to distinguish cassava isolates from milkweed isolates when grown on PDA agar or even to aid separation of species. To taxonomically distinguish between members of Sphaceloma, other methods had to be considered.

Isolates of $S$. manihoticola were obtained from infected cassava stems, leaves, and petioles at different sites in south-central Brazil. Isolates collected from milkweed at the same sites caused characteristic symptoms of superelongation when inoculated onto cassava plants. Using pathogenicity tests, 19 Sphaceloma isolates were selected for cassava. The isolates represented five genetic groups, four of which corresponded to groups $1,2,3$, and 4 , and were pathogenic on cassava. A fifth genetic group comprised two isolates, 1 and 6, nonpathogenic and highly pathogenic on cassava, and represented $S$. krugii from milkweed.

The cassava cv. MBRA 12 was resistant, whereas MBRA 703 was susceptible, to inoculation with most of the 19 Sphaceloma isolates evaluated. The more recently released cultivar (MBRA 703) was susceptible under greenhouse conditions, corroborating findings from disease evaluations made under field pressure conditions. Variation in virulence among disease reactions observed in the field and resulting from natural infection may reflect variation in resistance of materials planted in a given region. A differential genotype-isolate interaction was observed.

Isolates from cassava were differentiated from those from milkweed in both the PCR and restriction fragment length polymor- phism (RFLP) analysis of rDNA ITS regions and RAPD analysis. In the RFLP analysis, using five enzymes, the products of cassava isolates were of different sizes than those of milkweed isolates. Our results for the cassava isolates also agree with those reported by Alvarez et al. (1), having similar patterns and fragment sizes. Of the five enzymes used, $M s p I$ and $C f o I$ were the most useful for distinguishing cassava isolates from those of milkweed. The unique bands of 220 and 170 bp clearly differentiated cassava isolates from milkweed isolates.

Many loci were evident with each primer used in the RAPD analysis, which gave valuable information on the degree of variability and level of genetic relatedness among the 19 isolates representing the five groups.

A phylogenetic tree, based on RAPD banding patterns and using three random primers, distinguished between the cassava isolates of $S$. manihoticola and those of milkweed, and between $S$. manihoticola

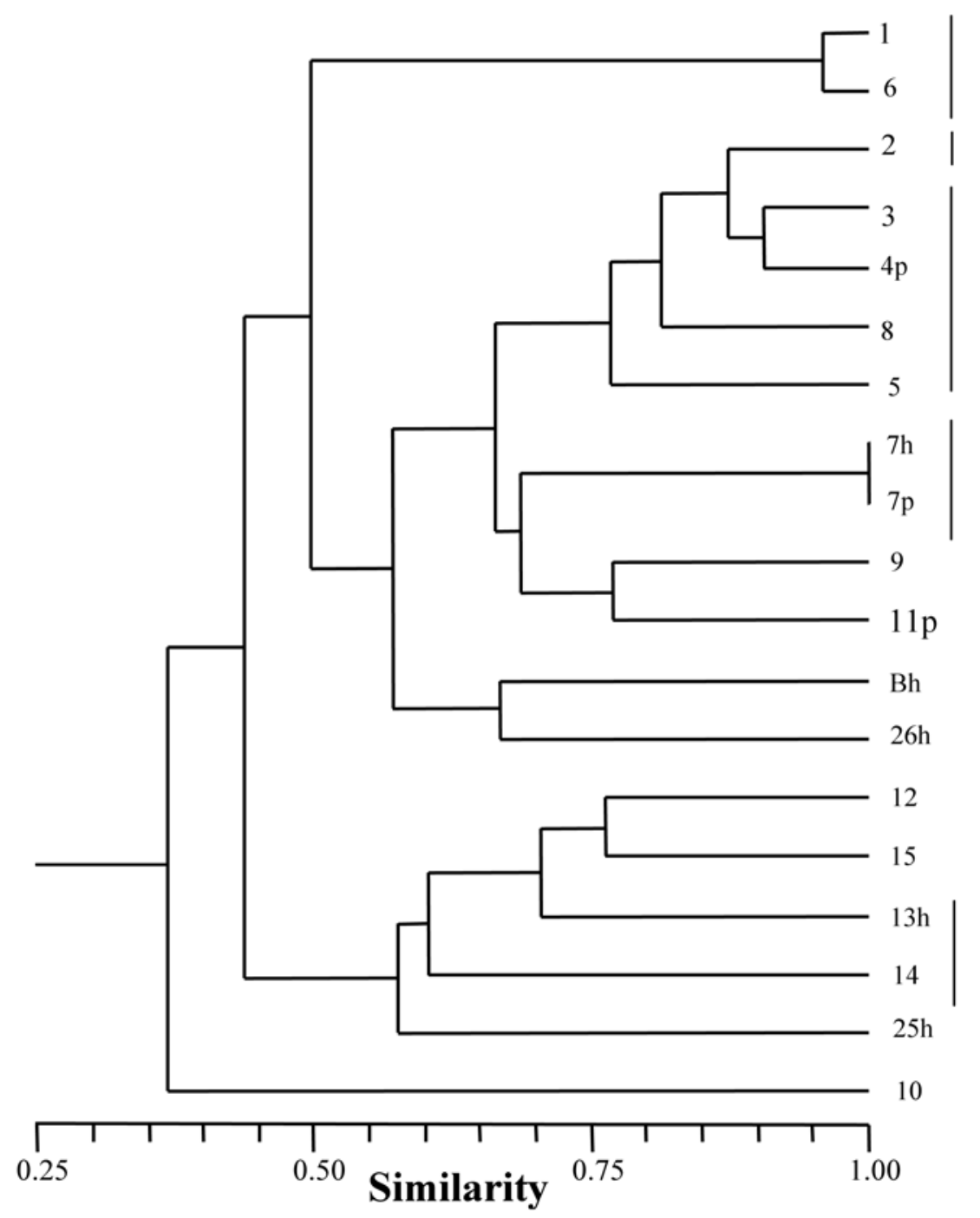

\begin{tabular}{l|l} 
Euphorbia & \\
heterophylla & Sao Paulo \\
Manihot esculenta & \\
Fibra & \\
& \\
Manihot esculenta & Paraná \\
IAC-13 & \\
& \\
Manihot esculenta & Sao Paulo \\
Roxinha & \\
$\begin{array}{l}\text { Manihot esculenta } \\
\text { IAC-12 } \\
\text { Manihot esculenta } \\
\text { Fibra } \\
\text { Manihot esculenta } \\
\text { unknown } \\
\text { Manihot esculenta } \\
\text { Experimental clone } \\
\text { Manihot esculenta } \\
\text { IAC-13 } \\
\text { Manihot esculenta } \\
\text { B. S. Catarina } \\
\begin{array}{l}\text { Manihot esculenta } \\
\text { Roxinha }\end{array}\end{array}$ \\
$\begin{array}{l}\text { Manihot esculenta } \\
\text { F1047 } \\
\text { Manihot esculenta } \\
\text { B. S. Catarina }\end{array}$ \\
\\
Sao Paulo \\
\\
\end{tabular}

Fig. 5. Similarity dendrogram of 19 isolates of Sphaceloma manihoticola, causal agent of superelongation disease in cassava (Manihot esculenta Crantz), collected from nine locations: Campos Novos, Paranavaí, Assis, Conchal, Platina, Candido Mota, Echaporá, Campo Grande, and Campinas in southcentral Brazil. States: Sao Paulo, Paraná, and Mato Grosso do Sul. Cultivars, Euphorbia heterophylla, Manihot esculenta: IAC-12 and IAC -13, F1047, Roxinha, Fibra, B.S. Catarina, and experimental clone. 
and S. krugii. In addition, the RAPD analysis clearly differentiated among the levels of genetic variation between the host-plant populations of $S$. manihoticola.

Cluster analysis separated the cassava and milkweed isolates into two distinct groups corresponding to the two species $S$. manihoticola and S. krugii, as described by Zeigler (19). The analysis also confirmed Zeigler's results, which found that more than one species of Sphaceloma infects cassava naturally.

Thus, our results demonstrated, through the RAPD analysis, polymorphism among cassava isolates of $S$. manihoticola from south-central Brazil and, hence, variability at both the pathogenicity and molecular levels. Both the RAPD and RFLP analyses provided genetic evidence of two wellcharacterized groups among tested isolates of S. manihoticola from cassava. The significance of these findings lies in fungal populations of high genetic variability being more able than populations of low genetic variability to develop resistance to fungicides and rapidly overcome host resistance $(11,14)$.

No correlation was found between the groups of isolates as identified by genetic and pathogenic characterizations of the pathogen, because of the smaller number of groups obtained with the Ward's cluster analysis compared with the Nei-Li coefficient of similarity. Increasing the number of isolates evaluated would improve the correlation of diversity between the RAPD groups and Ward's clusters, and would allow the diversity within each RAPD group to be more accurately evaluated. Correlation was not found among genetic grouping, pathogenicity, and geographic origin of S. manihoticola isolates from cassava.

To summarize, results of the RAPD and RFLP analyses provided genetic evidence of four well-characterized groups among tested isolates of $S$. manihoticola from cassava.

\section{LITERATURE CITED}

1. Alvarez, E., and Molina, M. L. 2000. Characterizing the Sphaceloma fungus, causal agent of superelongation disease in cassava. Plant Dis. 84:423-428.

2. Bitancourt, A. A., and Jenkins, A. E. 1950. Sphaceloma manihoticola sp. nov. Arq. Inst. Biol. Sao Paulo 20:15-16.

3. McDonald, B. A., and McDermontt, J. M. 1993. Population genetics of plant pathogenic fungi. Bioscience 43:311-319.

4. Centro Internacional De Agricultura Tropical (CIAT). 1973. Sistema de producción de yuca. Informe Anual 1:44-82.

5. Cock, J. H., and Lynam, J. K. 1991. La yuca en la economía de América Latina. In: Proyectos integrados de yuca. C. A. Pérez Crespo, ed. Centro Internacional de Agricultura Tropical (CIAT), Cali, Colombia. Documento Trabajo 79:18-27.

6. Food and Agriculture Organization, United Nations (FAO). 2000. FAO Bull. Stat. Rome 1:37-45.

7. González, D. O., Palacios, N., Gallego, G., and Thome, J., eds. 1995. Protocolos para marcadores moleculares. Unidad de Investigación en Biotecnología, Centro Internacional de Agricultura Tropical (CIAT), Cali, Colombia.

8. Instituto Brasileiro De Geografia E Estatística (IBGE). 1998. Anuario Estatistico do Brasil. Rio de Janeiro 58:3-31.

9. Lee, S. B., and Taylor, J. W. 1990. Isolation of DNA from fungal mycelia and single spores. Pages 282-287 in: PCR Protocols-A Guide to Methods and Applications M. A. Innes, D. H. Gelford, J. J. Sninsky, and T. J. White, eds. Academic Press Inc., San Diego, CA.

10. Lozano, J. C. 1977. Cassava superelongation. Cassava Newsl. 2:5-6.

11. Lozano, J. C., and Booth, R. H. 1974.
Enfermedades de la yuca. Folleto Técnico 5:48.

12. McIntosh, M. S. 1983. Analysis of combined experiments. Agron. J. 75:153-155.

13. Rondon, G. A., and Aponte, A. 1981. Estudio del superalargamiento de la yuca y búsqueda de cultivares tolerantes a la enfermedad. Fondo Nacional de Investigaciones Agropecuarias (FONAIAP), Maracay, Venezuela.

14. Sanchez, N. J. 1998. Caracterización de Phytophthora spp., agente causal de pudrición en la raíz de yuca (Manihot esculenta Crantz), utilizando pruebas de patogenicidad $y$ técnicas moleculares. Tesis de grado. Universidad Nacional de Colombia, Bogotá, Colombia.

15. Takatsu, A., and Fukuda, C. H. 1977. Recomedações e medidas a serem tomadas face á ocorrencia da superlongamento da mandioca, causada por Sphaceloma manihoticola na região Amazónica. Pages 5-6 in: Relatorio de inspeção fitosanitaria. EMBRAPA/CNPMF, Cruz das Almas, Brazil.

16. Valle, T. L., Kanthack, R. A. D., Lorenzi, J. O., Ribeiro, I. J. A., and Monteiro, D. A. 1996. Superalongamento possível ameaça a cultura da mandioca na região Centro-sul do Brasil. Congresso Brasileiro de Mandioca, IX. Resúmenes, no. 89. CERAT/UNESP-SBM, São Pedro, SP, Brazil.

17. Zeigler, R. S.1982. The superelongation disease of cassava: pathogen taxonomy, gibberellin production, and some characteristics of host resistance. Ph.D. thesis, Cornell University, Ithaca, NY.

18. Zeigler, R. S., Alvarez, E., and Lozano, J. C. 1983. Characteristics of cassava resistance to superelongation disease (Elsinoe brasiliensis). Trop. Pest Manage. 29:148-15.

19. Zeigler, R. S., and Lozano, J. C. 1983. The relationship of Sphaceloma and Elsinoe species pathogenic on cassava and other members of the Euphorbiaceae in Central and South America. Phytopathology 73:293300 .

20. Zeigler, R. S., Powell, L. E., and Thurston, D. 1980. Gibberellin A4 production by Sphaceloma manihoticola, causal agent of cassava superelongation disease. Phytopathology 70 589-593. 